\title{
DELAY RISK ASSESSMENT IN CRUSHER SYSTEM CONSTRUCTION AT PT FREEPORT INDONESIA UNDERGROUND MINE
}

\author{
Bambang Eka Muliano*)1, Idqan Fahmi*), Yudha Heryawan Asnawi*) \\ *) School of Business, Bogor Agricultural University \\ SB IPB Building, Pajajaran Road, Bogor, Indonesia 16151, Indonesia
}

\begin{abstract}
The construction of a crusher system is a very important sequence in the underground mining stage. Therefore, the delays in completing construction will have a negative effect on production achievement. Of the three crusher systems with a capacity of around 2,500 tons per hour that have been completed to support the development of a new underground mine at PT Freeport Indonesia (PTFI), two of them have experienced a delay in completion of more than one month while the remaining one was completed faster. This study aims to assess the risk of delays in the construction of a crusher system in PTFI's underground mine. The risk of delay was identified and registered from the history of the construction reports of the three previous crusher systems. Then the opinions of 35 selected experts are collected to provide an assessment on four scales of both consequences and likelihood scores. This expert assessment is used for risk analysis to determine the severity level of each risk. The result of this study identified 79 risks of delay in the construction of a crusher system in PTFI's underground mine which can be grouped into five categories: 16 risks related to work area, 8 risks related to construction drawing, 22 risks related to materials, 3 risks related to administration, and 30 risks related to resources. From the results of risk analysis and evaluation, it was found that 17 risks of high severity delays required risk treatment: 1 risk in the work area, 11 risks to material and 5 risks to resources. In very specific projects such as the construction of a crusher system in a remote underground mine, the risks related to materials and resources management are of high severity impact for project delays.
\end{abstract}

Keywords: construction delay analysis, construction failure case studies, construction risk assessment, project risk management

\begin{abstract}
Abstrak: Pembangunan crusher system adalah satu mata rantai sangat penting dalam tahapan tambang bawah tanah, sehingga keterlambatan penyelesaian pembangunannya akan berpengaruh negatif terhadap pencapaian produksi. Dari tiga crusher system berkapasitas sekitar 2.500 ton per jam yang telah selesai dibangun untuk mendukung pengembangan tambang bawah tanah baru di PT Freeport Indonesia (PTFI), dua mengalami keterlambatan penyelesaian lebih dari satu bulan dan satu selesai lebih cepat. Penelitian ini bertujuan untuk melakukan penilaian risiko keterlambatan pembangunan crusher system di tambang bawah tanah PTFI. Risiko keterlambatan diidentifikasi dan didaftar dari histori laporan pembangunan tiga crusher system terdahulu, kemudian mengajukan kepada 35 orang pakar untuk memberikan penilaian dalam 4 skala skor dampak (consequence) dan kemungkinan terjadinya (likelihood). Penilaian pakar ini digunakan untuk analisis risiko untuk menentukan tingkat signifikansi dari masing-masing risiko. Hasil penelitian ini berhasil mengidentifikasi 79 risiko keterlambatan konstruksi crusher system di tambang bawah tanah PTFI yang terbagi dalam lima kelompok: 16 risiko terkait area kerja, 8 risiko terkait gambar konstruksi, 22 risiko terkait material, 3 risiko terkait administrasi, dan 30 risiko terkait sumberdaya. Analisis dan evaluasi risiko memperoleh 17 risiko keterlambatan dalam kategori tingkat signifikansi besar dan harus ditindaklanjuti dengan perlakuan risiko: 1 risiko pada area kerja, 11 risiko pada material dan 5 risiko pada sumberdaya. Pada proyek sangat spesifik seperti pembangunan crusher system di tambang bawah tanah PTFI dengan lokasi terpencil, risiko-risiko terkait material dan sumberdaya memiliki tingkat signifikansi tinggi terhadap keterlambatan proyek.
\end{abstract}

Kata kunci: analisis keterlambatan konstruksi, studi kasus kegagalan konstruksi, penilaian risiko konstruksi, manajemen risiko proyek

\footnotetext{
${ }^{1}$ Corresponding author:

Email: rmuliano@fmi.com
} 


\section{INTRODUCTION}

Crusher system is first stage of mandatory mechanical equipment in production chain at a mineral mining operation (Wills and Napier-Munn, 2006). The crusher system grinds the blasted ore boulders into smaller sizes and transported by conveyor to the stockpile. In underground mining expansion, the construction of a crusher system is very important besides construction of draw points, or passes and ventilation system (Mahler and Sabirin, 2008). Delay of the crusher system operation at the scheduled time will disrupt the planned mining production target.

PT Freeport Indonesia (PTFI) is one of the world's largest copper and gold mining companies operating in the remote highlands of the Sudirman Mountains in Papua, Indonesia. Since the end of the Grasberg openpit mining at the end of 2019, all PTFI's reserves of 35.6 billion lbs. of copper and 29.1 million ounces of gold have been from underground mines (Freeport, 2020). In the expansion program of three new underground mines, PTFI required seven crusher systems with a capacity of around 2500 tons per hour in the underground mine. To build a crusher system in PTFI took about five years process from the initiation stage to completion of construction and commissioning. The construction phase is the most critical because it can only start after the excavation work and ground support in the crusher chamber has been completed by the development group. Complexity of constructability method and work sequence in tight schedule put the construction phase at risk of very large delay. Two of the three crusher systems that were constructed by PTFI Central Services division between 2014 and 2020 experienced a completion delay of more than a month while one was managed to be completed faster. Based on the analysis of annual report (Freeport, 2020), assuming that the other prerequisites are ready to operate, the potential for production loss per day caused by the delay in operation of the crusher system is equivalent to USD 2 million. Losses due to the delay in completing the crusher system construction are so great that it is very important to manage the delay factor in construction properly.

One of the main reasons for project failure is the occurrence of unexpected events that disrupt the progress of the project and cause irreversible deviations from the plan, some of which may have or can be known called risk (Hillson, 2009). Risk is a consequence of uncertainty which consists of the chance of occurring and how the consequences will affect the goal if the event happened (Cooper et al. 2005; BSI, 2018). The construction industry has higher risks and uncertainties compared to other industries (Flanagan and Norman, 1999). Successful projects usually happen because leaders recognize a lot of work in many projects, so they have notes and lessons from previous projects to identify potential problems as well as to plan project work as a whole to face the challenges ahead and anticipate many risks (Kendrick, 2015). Risk management is a coordinated and directed activity to manage risk which aims to identify and manage significant risks (Cooper et al. 2005; BSI, 2018). Project risk management aims to increase the probability and / or impact of positive risks also to reduce the probability and/or negative impact of project risks (PMI, 2017). Implementation of risk management can improve the competitiveness of organizations and their personnel (Priyarsono and Munawar, 2020).

In the context that the biggest potential failure of the crusher system project at the PTFI underground mine is the delay in the construction phase, the risks that have an impact on the delay in crusher construction must be managed properly. In order to properly manage the risk of construction delay, the organization should refer to the risk management processes in the standards and guidelines that are widely used around the world. The risk management process is a continuous and iterative process of setting context, risk assessment, risk treatment, communication, monitoring and recording (Cooper et al. 2005; BSI, 2018). The risk management process includes planning, identification, analysis, action plans, implementation plans and monitoring so that the chances of project success are optimal (PMI, 2017). This research focuses on assessing the risks of delays in the construction phase of the crusher system in an underground mine, by conducting a case study of the crusher system construction in PTFI's underground mine. Risk assessment includes risk identification, risk analysis and risk evaluation (BSI, 2018).

There have been many studies addressing the subject of construction delay analysis, but very few have discussed such a high complexity project like a crusher system in underground mines located in remote areas. The risk of delay in the construction phase found from previous studies includes: handing over area to the contractor (Abdullah and Alshibani, 2018); field actual conditions do not match the design (Rifai and Suef, 2018; Hong et al. 2017); geological condition (Zhang et al. 2020); 
environment(Egila et al. 2020); design quality (Mpofu et al. 2017; Hong et al. 2017; Zidane and Andersen, 2018; Jimoh et al. 2016); scope and design change (Mpofu et al. 2017; Hong et al. 2017; Zidane and Andersen 2018; Jimoh et al. 2016); materials (Iqbal et al. 2015; Rao et al. 2016; Zhang et al. 2020; Abdullah and Alshibani, 2018; Durdyev and Hosseini, 2019; Egila et al. 2020); administrative (Zidane and Andersen, 2018); resources (Egila et al. 2020; Iqbal et al. 2015; Derakhshanfar et al. 2019; Zidane and Andersen, 2018; Zhang et al. 2020; Durdyev and Hosseini, 2019); project management (Mpofu et al. 2017; Hong et al. 2017; Rao et al. 2016; Zidane and Andersen, 2018; Abdullah and Alshibani, 2018; Durdyev and Hosseini, 2019); project team communication and coordination (Caldas and Gupta, 2016; Rao et al. 2016; Linh and Hadikusumo, 2014; Zidane and Andersen, 2018; Abdullah and Alshibani, 2018; Durdyev and Hosseini, 2019); quality control (Linh and Hadikusumo, 2014; Zidane and Andersen, 2018); planning and scheduling (Mpofu et al. 2017; Caldas and Gupta, 2016; Linh and Hadikusumo, 2014; Zidane and Andersen, 2018; Abdullah and Alshibani, 2018; Durdyev and Hosseini, 2019); slow decision making (Zidane and Andersen, 2018); qualification of project stakeholders (Durdyev and Hosseini, 2019).

This research focuses on assessing the risks of construction delay. Risk assessment includes risk identification, risk analysis and risk evaluation (BSI, 2018). Risk identification is based on identification of risk root causes that affect the project and involve project stakeholders to ensure comprehensive risk identification (Freeport, 2018). One of the techniques to carry out risk identification is from the following three: (1) historical review; (2) current assessment; and (3) forecasting technique (PMI, 2009). Risk identification can also be done through expert judgment from similar projects including from post-review on completed projects (PMI, 2017; Cooper et al. 2005; Hillson, 2009).

The objectives of this study are: (1) to identify the risks that lead to delays in the completion of crusher system construction in underground mines; (2) to analyze the risks of delay in order to obtain the risk severity; (3) to evaluate the risks of delay against risk criteria to determine which risks need to be the focus of risk treatment.

\section{METHODS}

The research was conducted at PTFI Central Services Division's head office at Tembagapura, Papua, Indonesia. The document review and registration of construction delay risks were commenced within June to July 2020. The questionnaire distributed to the respondent by November 2020.

The research was collected two types of data. The first data are documents from the three crusher projects that have been completed previously. The researcher considered that the availability of data from the three previous PTFI's crusher projects on the similar context, actors and conditions was the most reliable data source for the delay risks identification in this case study. The second data is the result of questionnaire provided by researcher.

Risk identification used in this study was by using historical review and expert judgment (IEC, 2019; BSI, 2018; Freeport, 2018; PMI, 2017; PMI, 2009; Hillson, 2009; Cooper et al. 2005). The construction delay risks were registered from weekly progress reports, meeting minutes, monthly presentation slides when the three crusher system projects were constructed within 2013 to 2020. The registered construction delay risks were developed as questionnaire statement list to be distributed to respondents.

The questionnaire was distributed to 35 selected respondents to obtain a likelihood and consequence score for every single risks. Respondents were selected with criteria that was determined by the researcher to get respondents with certain considerations and criteria from researchers that aim to make the data obtained more representative (Sugiyono, 2008). The criteria of the respondent were determined so that people who are competent and have direct experience to the previous three crusher systems construction were selected. From there it was determined that there were 35 respondents who met the criteria. The respondents' characteristics regarding years of service, position in the organization, and involvement in the three previous crusher systems projects are shown in Table 1.

The questionnaire consisted of a list of identified risks of delay submitted to respondents to provide a score on both likelihood and consequence variables on each risk. Likelihood is defined as how often the possibility of a risk event occurring when the project is implemented 
according to plan. The scale of likelihood score ranged from 1 for very rare or unlikely to 4 for very frequent or almost certain as shown in Table 2. Consequence is defined as the qualitative and quantitative magnitude of the impact on project objectives if the risk event occurs. The scale of consequence score was from 1 for low impacts to 4 for major impacts as shown in Table 3 . Besides providing likelihood and consequence scores from the list of risks of delay stated in the questionnaire, respondents also provided the opportunity to adding up to three risks of delay that are considered significant and have not been stated in the risk registered in the questionnaire.
The results of the questionnaire from respondents were calculated to get the mode value from the likelihood score and the consequence score for all identified risks of delay. The use of the consequence and probability matrix analysis method is strongly applicable for carrying out the risk assessment stage since it fulfills the entire scope of risk identification, risk analysis and risk evaluation (IEC, 2019; Leśniak and Janowiec, 2019). The mode value of both likelihood and consequence was used to obtain a risk rating with the formula:

$$
\text { Risk Rating }=\text { Consequence } \times \text { Likelihood }
$$

Table 1. respondents' characteristics grouped by three expertise criteria

\begin{tabular}{lc}
\hline Respondent criteria to be defined & No. of respondent \\
\hline Year of Service: & 11 \\
5 to 10 years & 24 \\
More than 10 years & \\
Position in organization: & 1 \\
Vice President & 14 \\
Managers \& Assistant Managers & 2 \\
Technical Experts & 14 \\
Supervisors & 4 \\
Schedulers & \\
Involvement in the previous three crusher systems: & 27 \\
All three projects & 5 \\
Two projects & 3 \\
One project & 3 \\
\hline
\end{tabular}

Table 2. Risk probability of occurrence (Freeport, 2018)

\begin{tabular}{lcc}
\hline Qualitative Likelihood & Range of probability during project duration & Likelihood score \\
\hline Unlikely & $<5 \%$ probability & 1 \\
Possible & $5 \%$ to $30 \%$ probability & 2 \\
Likely & $31 \%$ to $75 \%$ probability & 3 \\
Almost certain & $>75 \%$ probability & 4 \\
\hline
\end{tabular}

Table 3. Consequence categories of impact to project goals (Freeport 2018)

\begin{tabular}{lcc}
\hline Consequence categories & Magnitude of impact to project goals & Consequence score \\
\hline Minor & Low impact on cost/schedule if risk occurs & 1 \\
Moderate & Medium impact on cost/schedule if risk occurs & 2 \\
Significant & High level of impact on cost/schedule if risk occurs & 3 \\
Major & Very high impact on cost/schedule if risk occurs & 4 \\
\hline
\end{tabular}


This risk rating is used to quantify the severity level of each risk using the $4 \mathrm{X} 4$ risk assessment matrix in Table 4. The range of possible risk rating from 1 to 16 . The level of risk severity and risk management mitigation response that is required for the associated rating is shown in Table 5 (Freeport, 2018).

This research was initiated from the huge financial loss caused by the delay in completing the construction of the crusher system at PTFI's underground mine. Meanwhile, the construction phase of the crusher system installation has a very large risk of delays. Experienced by the three previous similar projects, two projects experienced delays of more than one month. The identification of the risk of delay is collected from historical data of previous projects. The results of risk identification were compiled in a questionnaire and distributed to 35 selected respondents to provide the likelihood and consequence score for each identified risk of delay and adding other risks which were in the questionnaire list. The likelihood and consequence scores of every single delay risk were calculated to obtain a risk rating and categorized by risk severity. From this analysis, acceptable risks and unacceptable risks are obtained. The risks with risk rating above the risk criteria are unacceptable risks with large significance effect to construction delay and require risk treatment. The research framework is shown in Figure 1.

\section{RESULTS}

The research was identified 79 risks of delay in PTFI's underground mine crusher system construction. The construction delay risks were grouped in to five risk sources: work area, construction drawing, material, administration, and resources. The risks were categorized to three severity level: minor, medium, and actionable.

\section{Work area}

The construction delay risks related to work area is in line with previous studies (Zhang et al. 2020; Abdullah and Alshibani, 2018; Rifai and Suef, 2018). In the PTFI's underground mine crusher system work area has very limited space and access. The crusher system was built in three different levels of special chamber with narrow access located 5 kilometers away from entrance portal. The chambers were developed by area owner based on chamber excavation and ground support design. Construction will start once ground support activities are completed and services source for construction activities such as ventilation, power, water and compressed air are available. There were 16 construction delay risks identified related to the work area and access. Table 6 illustrates the risk rating calculation from respondent's scores of likelihood and consequence resulted in risk rating range from 1 to 9 , of which 8 risks were categorized as low severity, 7 risks were categorized as medium severity and one risk was categorized as actionable severity that required to be treated.

Table 4. The 4 X 4 Risk assessment matrix (Freeport, 2018)

\begin{tabular}{lcccc}
\hline \multirow{2}{*}{ Likelihood Scores } & \multicolumn{4}{c}{ Consequence Scores } \\
\cline { 2 - 5 } & $1-$ minor & $2-$ moderate & 3 -significant & $4-$ major \\
\hline $1-$ unlikely & 1 & 2 & 3 & 4 \\
$2-$ possible & 2 & 4 & 6 & 8 \\
$3-$ likely & 3 & 6 & 9 & 12 \\
$4-$ almost certain & 4 & 8 & 12 & 16 \\
\hline
\end{tabular}

Table 5. Risk severity level of risk rating and response type (Freeport, 2018)

\begin{tabular}{lcl}
\hline Risk severity level & Range of Risk Rating & \multicolumn{1}{c}{ Risk management mitigation response } \\
\hline Low & 1 to 3 & $\begin{array}{l}\text { Acceptable risks: the impact would be sufficiently low and/or the } \\
\text { probability of occurring so small that no special measures to mitigate the } \\
\text { risk are normally considered appropriate }\end{array}$ \\
Medium & 4 to 6 & $\begin{array}{l}\text { Acceptable risk, no treatment plan required, but some monitoring may be } \\
\text { needed } \\
\text { Monitor }\end{array}$ \\
Actionable & 8 or greater & Treatment plan required, identify milestones to be accomplished \\
\hline
\end{tabular}




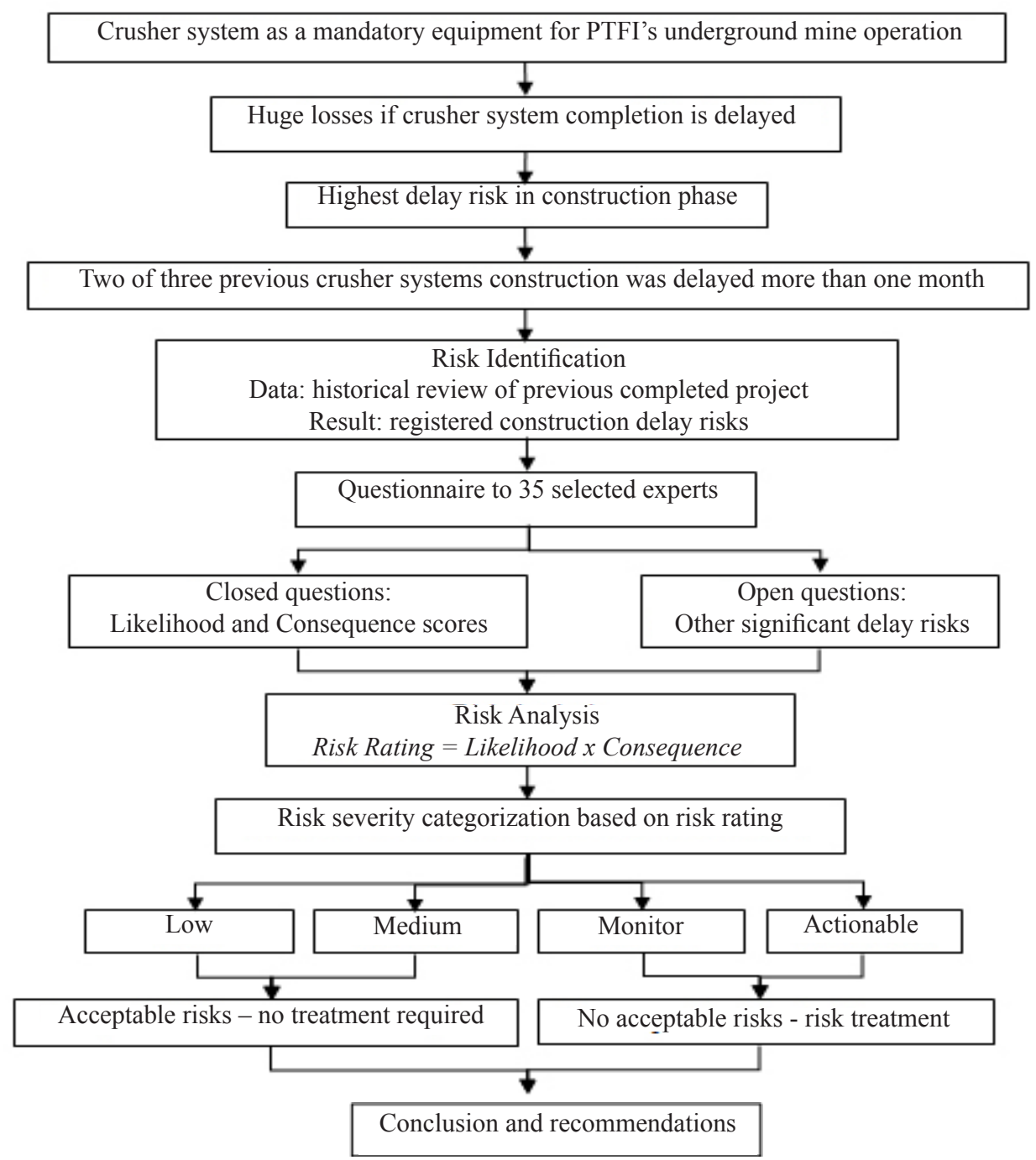

Figure 1 Research framework

Table 6. Analysis of construction delay risks related to work area and access

\begin{tabular}{clcccc}
\hline Risk ID & Construction delay risks description & L & C & R & Risk severity \\
\hline A.01 & $\begin{array}{l}\text { Additional works in the beginning due to insufficient actual space of chamber } \\
\text { area to design }\end{array}$ & 3 & 3 & 9 & Actionable \\
A.02 & Sharing access or working time with development team & 2 & 2 & 4 & Medium \\
A.03 & Delay hand over remaining area & 3 & 2 & 6 & Medium \\
A.04 & Power availability issue & 2 & 2 & 4 & Medium \\
A.05 & Service water availability issue & 2 & 1 & 2 & Low \\
A.06 & Compressed service air availability issue & 2 & 2 & 4 & Medium \\
A.07 & Interrupted due to seismic event evacuation & 2 & 1 & 2 & Low \\
A.08 & Interrupted due to hazardous gas event evacuative & 1 & 1 & 1 & Low \\
A.09 & Interrupted due to ventilation system issue & 2 & 1 & 2 & Low \\
A.10 & Interrupted due to broken ground support event & 1 & 1 & 1 & Low \\
A.11 & Suspended due to geotechnical observation/investigation & 2 & 1 & 2 & Low \\
A.12 & Suspended during repair ground support/shotcrete & 2 & 2 & 4 & Medium \\
A.13 & Suspended during slashing/chipping at tight spot & 2 & 2 & 4 & Medium \\
A.14 & Suspended due to flooding at access & 2 & 1 & 2 & Low \\
A.15 & Interrupted due to access blockage by broken heavy equipment & 1 & 1 & 1 & Low \\
A.16 & Suspended during accident investigation & 2 & 2 & 4 & Medium \\
\hline
\end{tabular}

Notes: $\mathrm{L}=$ likelihood; $\mathrm{C}=$ consequence; $\mathrm{R}=$ risk rating $(\mathrm{L} \times \mathrm{C})$ 


\section{Construction drawing}

The construction delay risks related to construction drawing is in line with previous studies (Zidane and Andersen, 2018; Mpofu et al. 2017; Hong et al. 2017; Jimoh et al. 2016). In the PTFI's underground mine crusher system construction drawing was mainly provided by third party engineering company located in New Orleans, USA. Minor changes to fit the actual field condition is done by site engineering team. There were 8 construction delay risks identified related to the construction drawing. Table 7 illustrates the risk rating calculation from respondent's scores of likelihood and consequence resulted in risk rating 4 , which was categorized as medium severity and no risk treatment required.

\section{Material}

The construction delay risks related to material is in line with previous studies (Zhang et al. 2020; Egila et al. 2020; Durdyev and Hosseini, 2019; Abdullah and Alshibani, 2018; Rao et al. 2016; Iqbal et al. 2015). The PTFI's crusher system main materials are specific, big size and heavy. The manufacturing time about 14 months and another three months of shipping time from Germany. Arriving on site, the material will be stored in lowland area due to very limited storage area in highland. The material will be delivered to highland close to installation time. There were 22 construction delay risks identified related to material. Table 8 illustrates the risk rating calculation resulted in range from 4 to 9 , of which 11 risks were categorized as medium severity and the other 11 were categorized as actionable severity that required to be treated.

\section{Administration}

The construction delay risks related to administration is in line with previous study (Zidane and Andresen, 2018). In the PTFI's underground mine crusher system has very specific equipment produced in Germany such as crusher, apron feeder and rock breaker. The representative of the equipment's principle usually commences supervision and witness during the installation for warranty and insurance purpose. There were 3 construction delay risks identified related to the administration process required to bring the principle representative to the site. Table 9 illustrates the risk rating calculation from respondent's scores of likelihood and consequence resulted risk rating range from 1 to 4 , of which 2 risks were categorized as medium severity and 1 risk was categorized as low severity. No treatment required for those risks.

Table 7. Analysis of construction delay risks related to construction drawing

\begin{tabular}{clcccl}
\hline Risk ID & Construction delay risks description & L & C & R & Risk severity \\
\hline B.01 & Suspended due to waiting for the DED & 2 & 2 & 4 & Medium \\
B.02 & Suspended due to DED in revision process & 2 & 2 & 4 & Medium \\
B.03 & Suspended due to additional scope in critical sequence waiting for new drawing & 2 & 2 & 4 & Medium \\
B.04 & Interrupted due to unclear drawing (confusing) & 2 & 2 & 4 & Medium \\
B.05 & Suspended due to incomplete drawing & 2 & 2 & 4 & Medium \\
B.06 & Suspended due to inconsistency drawings & 2 & 2 & 4 & Medium \\
B.07 & Rework due to construction team referring to obsolete drawing & 2 & 2 & 4 & Medium \\
B.08 & Rework due to new revision drawing issued after the construction work is & 2 & 2 & 4 & Medium \\
& completed & & & & \\
\hline
\end{tabular}

Notes: $\mathrm{L}=$ likelihood; $\mathrm{C}=$ consequence; $\mathrm{R}=$ risk rating $(\mathrm{L} \times \mathrm{C})$ 
Table 8. Analysis of construction delay risks related to material

\begin{tabular}{clllll}
\hline Risk ID & Construction delay risks description & L & C & R & Risk severity \\
\hline C.01 & Material delivery issue & 3 & 3 & 9 & Actionable \\
C.02 & Incomplete material received & 3 & 3 & 9 & Actionable \\
C.03 & Substandard material received & 2 & 3 & 6 & Medium \\
C.04 & Broken material received & 2 & 2 & 4 & Medium \\
C.05 & Material broken in storage & 3 & 3 & 9 & Actionable \\
C.06 & Material broken during installation & 3 & 3 & 9 & Actionable \\
C.07 & Additional scope with no material available & 3 & 3 & 9 & Actionable \\
C.08 & Material missing in storage & 3 & 3 & 9 & Actionable \\
C.09 & Untracked materials used by other projects & 3 & 3 & 9 & Actionable \\
C.10 & Replacement material delivery issue & 3 & 3 & 9 & Actionable \\
C.11 & Material missing after installation & 2 & 3 & 6 & Medium \\
C.12 & Concrete supply issue & 2 & 2 & 4 & Medium \\
C.13 & Substandard concrete supply & 2 & 2 & 4 & Medium \\
D.01 & Steel fabrication design issue & 2 & 2 & 4 & Medium \\
D.02 & Steel fabrication progress issue & 3 & 3 & 9 & Actionable \\
D.03 & Steel fabrication delivery issue & 3 & 3 & 9 & Actionable \\
D.04 & Incomplete steel fabrication issue & 3 & 3 & 9 & Actionable \\
D.05 & Fabricated steel doesn't match the drawing & 2 & 2 & 4 & Medium \\
D.06 & Field modification due to new revision design of fabricated steel & 2 & 2 & 4 & Medium \\
D.07 & Shop modification due to new revision design of fabricated steel & 2 & 2 & 4 & Medium \\
D.08 & Field modification due to fabricated steel doesn't fit each other & 2 & 2 & 4 & Medium \\
D.09 & Field modification due fabricated steel doesn't match the actual field condition & 2 & 2 & 4 & Medium \\
\hline
\end{tabular}

Notes: $\mathrm{L}=$ likelihood; $\mathrm{C}=$ consequence; $\mathrm{R}=$ risk rating $(\mathrm{L} \times \mathrm{C})$

Table 9. Analysis of construction delay risks related to administration

\begin{tabular}{clcccl}
\hline Risk ID & Construction delay risks description & L & C & R & Risk severity \\
\hline E.01 & VISA for special equipment principle representative site visit & 2 & 2 & 4 & Medium \\
E.02 & Principle representative competency issue & 2 & 2 & 4 & Medium \\
E.03 & Principle representative VISA duration issue & 1 & 1 & 1 & Low \\
\hline
\end{tabular}

Notes: $\mathrm{L}=$ likelihood; $\mathrm{C}=$ consequence; $\mathrm{R}=$ risk rating $(\mathrm{L} \times \mathrm{C})$

\section{Resources}

The construction delay risks related to resources is in line with previous studies (Egila et al. 2020; Zhang et al. 2020; Durdyev and Hosseini, 2019; Derakhsanfar et al. 2019; Zidane and Andersen, 2018; Iqbal et al. 2015). Construction of the crusher system was carried out using PTFI's own resources. PTFI has dedicated construction manpower and equipment to support both mine expansion and operation maintenance projects. Besides the crusher system project, the resources also worked on around 10 other projects in parallel, with various sizes and levels of priority. Immediate increase in manpower is infeasible due to very limited accommodation available, especially in highland area. There were 30 construction delay risks identified related to resources. Table 10 illustrates the risk rating calculation from respondent's scores of likelihood and consequence resulted in risk rating range from 4 to 9 , of which 25 risks were categorized as medium severity and 5 risks were categorized as actionable severity that required to be treated. 
Table 10. Analysis of construction delay risks related to resources

\begin{tabular}{|c|c|c|c|c|c|}
\hline Risk ID & Construction delay risks description & $\mathrm{L}$ & $\mathrm{C}$ & $\mathrm{R}$ & Risk severity \\
\hline F.01 & $\begin{array}{l}\text { Suspended due to construction manpower moved to unplanned emergency } \\
\text { project }\end{array}$ & 3 & 3 & 9 & Actionable \\
\hline F.02 & Suspended due to engineering manpower moved to unplanned emergency project & 2 & 2 & 4 & Medium \\
\hline F.03 & Suspended due to QC manpower moved to unplanned emergency project & 2 & 2 & 4 & Medium \\
\hline F.04 & $\begin{array}{l}\text { Interrupted due to construction manpower also working on other project(s) with } \\
\text { the same priority }\end{array}$ & 3 & 2 & 6 & Medium \\
\hline F.05 & $\begin{array}{l}\text { Interrupted due to engineering manpower also working on other project(s) with } \\
\text { the same priority }\end{array}$ & 2 & 2 & 4 & Medium \\
\hline F.06 & $\begin{array}{l}\text { Interrupted due to QC manpower also working on other project(s) with the same } \\
\text { priority level }\end{array}$ & 2 & 2 & 4 & Medium \\
\hline F.07 & Transportation to project location issue & 2 & 2 & 4 & Medium \\
\hline F.08 & Main road access blockage issue & 2 & 2 & 4 & Medium \\
\hline F.09 & Suspended due to labor strike issue & 2 & 2 & 4 & Medium \\
\hline G.01 & $\begin{array}{l}\text { Suspended due to mobile lifting equipment moved to unplanned emergency } \\
\text { project }\end{array}$ & 2 & 3 & 6 & Medium \\
\hline G.02 & $\begin{array}{l}\text { Interrupted due to mobile lifting equipment also working on other project(s) with } \\
\text { the same priority }\end{array}$ & 3 & 3 & 9 & Actionable \\
\hline G.03 & $\begin{array}{l}\text { Suspended due to operator of mobile lifting equipment moved to unplanned } \\
\text { urgent project }\end{array}$ & 3 & 3 & 9 & Actionable \\
\hline G.04 & $\begin{array}{l}\text { Interrupted due to operator of mobile lifting equipment also working on other } \\
\text { project(s) with the same priority level }\end{array}$ & 3 & 2 & 6 & Medium \\
\hline G.05 & $\begin{array}{l}\text { Interrupted due scaffolding specialist crew also working on other project(s) with } \\
\text { the same priority }\end{array}$ & 3 & 3 & 9 & Actionable \\
\hline G.06 & Interrupted due to broken mobile lifting equipment & 2 & 2 & 4 & Medium \\
\hline G.07 & $\begin{array}{l}\text { Suspended due to scaffolding material also working on other project(s) with the } \\
\text { same priority }\end{array}$ & 3 & 2 & 6 & Medium \\
\hline G.08 & $\begin{array}{l}\text { Interrupted due to drilling machine operator also working on other project(s) with } \\
\text { the same priority }\end{array}$ & 3 & 2 & 6 & Medium \\
\hline G.09 & $\begin{array}{l}\text { Interrupted due to drilling machine also working on other project(s) with the } \\
\text { same priority level }\end{array}$ & 3 & 2 & 6 & Medium \\
\hline G.10 & Interrupted due to broken drilling machine & 2 & 2 & 4 & Medium \\
\hline H.01 & Worker is not aware of the project completion target & 2 & 2 & 4 & Medium \\
\hline H.02 & Field supervisor are not aware of the project completion target & 2 & 3 & 6 & Medium \\
\hline H.03 & $\begin{array}{l}\text { Approved baseline schedule without contingency for additional/change scope } \\
\text { during construction }\end{array}$ & 2 & 3 & 6 & Medium \\
\hline H.04 & Lack of communication and coordination & 2 & 3 & 6 & Medium \\
\hline H.05 & $\begin{array}{l}\text { Interrupted due to supervisor also working on other project(s) with the same } \\
\text { priority level }\end{array}$ & 3 & 3 & 9 & Actionable \\
\hline H.06 & Suspended due to conflict sequence between actual and approved schedule & 3 & 2 & 6 & Medium \\
\hline H.07 & Field supervisor doesn’t have proper daily plan & 2 & 3 & 6 & Medium \\
\hline H.08 & Field worker doesn't obey the supervisor's direction & 2 & 2 & 4 & Medium \\
\hline H.09 & $\begin{array}{l}\text { Different priority and work sequence between field supervisors from different } \\
\text { disciplines }\end{array}$ & 2 & 2 & 4 & Medium \\
\hline H.10 & Different priority and work sequence in construction management & 2 & 2 & 4 & Medium \\
\hline H.11 & Change in sequence and priority whenever there is a change in supervision & 2 & 2 & 4 & Medium \\
\hline
\end{tabular}

Notes: $\mathrm{L}=$ likelihood; $\mathrm{C}=$ consequence; $\mathrm{R}=$ risk rating $(\mathrm{L} \times \mathrm{C})$ 
Table 11 illustrate the summary of risks group by severity level which 9 risks were categorized as low severity, 53 risks were categorized as medium severity, no risk was categorized as special monitor and 17 risks were categorized as actionable severity. The 17 risks were categorized as actionable severity will be required the risk treatment: (1) Additional works in the beginning due to insufficient actual space of chamber area to design; (2) Material delivery; (3) Incomplete material received; (4) Material broken in storage; (5) Material broken during installation; (6) Additional scope with no material available; (7) Material missing in storage; (8) Untracked materials used by other projects; (9) Replacement of broken/missing material delivery; (10) Structural steel fabrication progress; (11) Structural steel fabrication delivery; (12) Incomplete structural steel fabrication received; (13) suspended due to construction manpower moved to unplanned emergency project; (14) Interrupted due to mobile lifting equipment also working on other project(s) with the same priority level; (15) Suspended due to operator of mobile lifting equipment moved to unplanned emergency project; (16) Interrupted due scaffolding specialist crew also working on other project(s) with the same priority level; and (17) Interrupted due to supervisor also working on other project(s) with the same priority level.

\section{Managerial Implications}

This study provides the assessment of delay risks in the construction of the crusher system at PTFI's underground mine. The and categorizing those risks into acceptable risks and actionable risks which require treatment. This study provides the delay risks assessment in crusher system construction at PTFI's underground mines constructed by the Central Services division, consisting of risks that are acceptable and risks that require treatment. Although it is assessed that $79 \%$ of the risks are categorized as acceptable under the existing control system, they should always be monitored until the end of the project. For $21 \%$ of risks that require treatment, PTFI must formulate the mitigation action plan to minimize their impact or exploit them became opportunities.

\section{CONCLUSIONS AND RECOMMENDATIONS}

\section{Conclusions}

Crusher system construction in PTFI's underground mine identified 79 risks of delay that could impact the completion target. They can be grouped into five risk sources: 16 risks related to work area, 8 risks related to construction drawing, 22 risks related to materials, 3 risks related to administration and 30 risks related to resources.

Of the 79 risks identified, $11 \%$ were categorized as low severity, $68 \%$ were categorized as medium severity, no risk was categorized as to be monitored and $21 \%$ were categorized as actionable severity. This means that $79 \%$ were acceptable and require no treatment, and the remaining $21 \%$ require risk treatment.

Table 11. Summary of delay risk categories by risk severity level

\begin{tabular}{lccc}
\hline \multicolumn{1}{c}{ Delay risk categories } & No. of risks & Risk severity level & Percentage (\%) \\
\hline Work area & 8 & Low & 11 \\
Administration & 1 & & 68 \\
Work area & 7 & Medium & \\
Construction Drawing & 8 & & \\
Material & 11 & & \\
Administration & 2 & & \\
Resources & 25 & Actionable & \\
Work area & 1 & & \\
Material & 11 & & 100 \\
Resources & 5 & & \\
\hline \multicolumn{2}{l}{} \\
\hline
\end{tabular}


The $21 \%$ actionable risks that require risk treatment are: (1) Additional works in the beginning due to insufficient actual space of chamber area to design; (2) Material delivery; (3) Incomplete material received; (4) Material broken in storage; (5) Material broken during installation; (6) Additional scope with no material available; (7) Material missing in storage; (8) Untracked materials used by other projects; (9) Replacement of broken/missing material delivery; (10) Structural steel fabrication progress; (11) Structural steel fabrication delivery; (12) Incomplete structural steel fabrication received; (13) suspended due to construction manpower moved to unplanned emergency project; (14) Interrupted due to mobile lifting equipment also working on other project(s) with the same priority level; (15) Suspended due to operator of mobile lifting equipment moved to unplanned emergency project; (16) Interrupted due scaffolding specialist crew also working on other project(s) with the same priority level; and (17) Interrupted due to supervisor also working on other project(s) with the same priority level.

\section{Recommendations}

This is a preliminary research to assess delay risks in the crusher system construction at PTFI's underground mine carried out by Central Services division. The result of this research suggests that further study is required to develop detailed treatment as part of the strategic mitigation plan. It is recommended that the delay risks identification study can be continued in a broader scale that includes overall crusher system project in PTFI's underground mine from the initial stage until completion, including external stakeholders' involvement in the project.

\section{REFERENCES}

Abdullah RA, Alshibani A. 2018. Critical factors behind construction delay in petrochemical projects in Saudi Arabia. Energies 11(7):1-18. https://doi. org/10.3390/en11071652

[BSI] British Standard Institution. 2018. BS ISO 31000:2018 Risk Management - Guidelines second edition. London: BSI Standards Limited 2018.

Caldas C, Gupta A. 2016. Critical factors impacting the performance of mega-projects. Engineering, Construction and Archictural Management 24(6):920-934. https://doi.org/10.1108/ECAM-

\section{5-2016-0117}

Cooper D, Grey S, Raymond G, Walker P. 2005. Project Risk Management Guidelines Managing Risk in Large Projects and Complex Procurements. West Sussex: John Wiley \& Sons Ltd.

Derakhshanfar H, Ochoa JJ, Kirytopoulos K, Mayer W, Tam VW. 2019. Construction delay risk taxonomy, associations and regional contexts A systematic review and meta-analysis. Engineering, Construction and Archictural Management 26(10):2364-2388. https://doi. org/10.1108/ECAM-07-2018-0307

Durdyev S, Hosseini MR. 2019. Causes of delays on construction projects: A comprehensive list. International Journal of Managing Projects in Business 13(1):20-46. https://doi.org/10.1108/ IJMPB-09-2018-0178

Egila AE, Balogun OA, Yusuf SO. 2020. Assessment of delay and cost-overrun in federal road construction project in Abuja. Independent Journal of Management \& Production 11(4):1184-1200. https://doi.org/10.14807/ijmp. v11i4.1065

Flanagan R, Norman G. 1999. Risk Management and Construction. London: Blackwell Science Ltd.

[Freeport] Freeport McMoRan. 2018. Risk Management Standard Process Revision 3. Phoenix: FreeportMcMoRan.

[Freeport] Freeport McMoRan. 2020. FCX Annual Report 2019. Phoenix: Freeport-McMoRan.

Hillson D. 2009. Managing Risk in Projects. Surrey: Gower Publishing Ltd.

Hong VA, Viet CH, Min LX, Wang JQ. 2017. Risk analysis of schedule delays in international highway projects in Vietnam using a structural equation model. Engineering, Construction and Architectural Management 24(6):1018-1039. https://doi.org/10.1108/ECAM-06-2016-0138

[IEC] International Electrotechnical Commissioning. 2019. IEC 31010 International Standard, Risk management - Risk Assessment techniques. Geneva: IEC.

Iqbal S, Choudhry RM, Holschemacher K, Ali A, Tamosaitiene J. 2015. Risk management in construction projects. Technological and Economic Development of Economy 21(1): 6578. https://doi.org/10.3846/20294913.2014.994 582

Jimoh RA, Sani MA, Adoza AI, Yahaya I. 2016. Managing pre-construction and construction risks on project sites in Abuja-Nigeria. Civil 
Engineering Dimension 18(1): 1-7. https://doi. org/10.9744/ced.18.1.1-7

Kendrick T. 2015. Identifying and Managing Project Risk - Essential Tools for Failure-Proofing Your Project third edition. New York: American Management Association.

Leśniak A, Janowiec F. 2019. Risk assessment of additional works in railway construction investments using the bayes network. Sustainability 11(19):53-88. https://doi. org/10.3390/su11195388

Linh HP, Hadikusumo H. 2014. Schedule delays in engineering, procurement, and construction petrochemical projects in vietnam: A qualitative research study. International Journal of Energy Sector Management 8(1):13-26. https://doi. org/10.1108/IJESM-06-2013-0009

Mahler A, Sabirin N. 2008. Dari Grasberg sampai Amamapare: Proses Penambangan Tembaga \& Emas Mulai Hulu hingga Hilir. Jakarta: Gramedia.

Mpofu B, Edward GO, Moobela C, Pretorius A. 2017. Profiling causative factors leading to construction project delays in the United Arab Emirates. Engineering, Construction and Architectural Management 24(2):346-376. https://doi. org/10.1108/ECAM-05-2015-0072

Priyarsono DS, Munawar Y. 2020. Pengembangan SDM untuk implementasi manajemen risiko: perspektif baru dari sudut pandang pengguna. Jurnal Aplikasi Bisnis dan Manajemen (JABM) 6(3):478-488.https://doi.org/10.17358/ jabm.6.3.478

[PMI] Project Management Institute. 2009. Practice Standard for Project Risk Management. Pennsylvania: Project Management Institute.

[PMI] Project Management Institute. 2017. A Guide to the Project Management Body of Knowledge (PMBOK Guide) sixth edition. Pennsylvania: Project Management Institute.

Rao BP, Shekar SC, Jaiswal N, Jain A, Saxena AD. 2016. Delay analysis of construction projects. Journal of Information Technology and Economic Development 7(1):15-24.

Rifai W, Suef M. 2018. Risk analysis of project construction delay of Spazio Tower - 2 Surabaya. International Journal of Innovative Science and Research Technology 4(1):361-370.

Sugiyono. 2008. Metode Penelitian Kuantitatif, Kualitatif dan $R \& D$. Bandung: Alfabeta.

Wills BA, Napier-Munn TJ. 2006. Wills' Mineral Processing Technology an Introduction to the Practical Aspects of Ore Treatment and Mineral Recovery. Ed. ke-7. Elsevier Science \& Technology Books.

Zhang D, Zhang H, Cheng T. 2020. Causes of delay in the construction projects of subway tunnel. Advances in Civil Engineering :1-4.

Zidane YJ,Andersen B. 2018. The top 10 universal delay factors in construction projects. International Journal of Managing Projects in Business 11(3):650-672. 